\title{
42. CONGLOMERATES OF VOLCANIC ROCKS OF DEEP SEA DRILLING PROJECT SITE 439
}

\author{
Kantaro Fujioka, Ocean Research Institute, University of Tokyo, Nakano, Tokyo, Japan
}

\begin{abstract}
Acidic to intermediate volcanic rocks were obtained as boulders, pebbles, and clasts with intercalated matrix sediments near the Japan Trench. A 47.5-meter conglomerate bed unconformably overlies acoustic basement consisting of Upper Cretaceous siltstone and is overlain in turn by massive coarse-sandstone and siltstone beds with many fossil mollusks. The volcanic cobbles and boulders in the conglomerate show pronounced porphyritic texture. Their phenocrysts are plagioclase, hornblende, and biotite; the groundmass consists of plagioclase, K-feldspar, quartz, iron oxide, and altered interstitial glass.

The Plagioclase content of these volcanic rocks is very high, whereas iron oxide minerals are rare. The chemical composition of these volcanic rocks was analyzed to determine the rock series. Matrix sediments were also analyzed chemically, and their chemical composition was found to be similar to that of volcanic rocks, except for a lower $\mathrm{CaO}$ content. $\mathrm{SiO}_{2}$ content of the volcanic rocks ranges from 60.23 to 73.90 , corresponding to that of andesite to rhyolite.

All the samples show extremely high $\mathrm{Al}_{2} \mathrm{O}_{3}$ content, which reflects the high amounts of modal plagioclase.

These volcanic rocks belong to both the calc-alkalic and tholeiitic rock series, and the differentiation trend is controlled by fractional crystallization, mainly of plagioclase, K-feldspar, and hornblende. The assemblage of calc-alkalic and tholeitic rock series is frequently observed in island arcs and active continental margins. These volcanic rocks are derived from the Oyashio ancient landmass, which is a slightly matured island arc (see site chapters, this volume, Pt. 1).
\end{abstract}

\section{INTRODUCTION}

At DSDP Site 439 , acidic volcanic rocks were recovered in Core 32, below a unit consisting of massive sandstone and siltstone beds. These acidic volcanic rocks are the first recovered during DSDP drilling. The volcanic rocks occur as boulders, pebbles, and clasts in a 47.5-meter conglomerate bed of Lithologic Unit 6 at Sites 438 and 439 . No plutonic rocks, such as granite and granodiorite, were found. The largest boulder of volcanic rock is about $70 \mathrm{~cm}$. Clasts of sedimentary rocks also occur throughout the conglomerate bed. These clasts are always angular to subangular. Smallscale grading of clasts is locally observed in Unit 6. Judging by the angular sedimentary clasts, the large size of boulders, and the absence of definite marine fossils in the matrix, the source region for the conglomerate cannot be very far from Site 439 .

The multichannel airgun records suggest that the Upper Cretaceous acoustic basement rises gradually eastward from this site. A significant hiatus exists between the Upper Creatceous siltstone of Unit 7 and the conglomerate bed of Unit 6 .

The shipboard scientists have proposed the existence of an exposed landmass called the Oyashio ancient landmass (von Huene, Nasu, et al., 1978). In order to determine the volcanic rock series of these conglomerates and the features of volcanism, I performed major-element chemical analyses by X-ray fluorescence (XRF), using the fusion method.

In this article, I discuss the volcanic rock series of these conglomerates and their provenance.

\section{PETROGRAPHY OF VOLCANIC ROCKS}

Conglomerates of Lithologic Unit 6 contain clasts of volcanic rocks which exhibit a pronounced porphyritic texture; their phenocrysts consist of plagioclase, hornblende, and biotite (rarely), and their groundmass consists of plagioclase, K-feldspar, quartz, iron oxide, and altered interstitial glass. The amount of mafic minerals is always less than 15 per cent. The color index of volcanic rocks is very low. The amount of modal plagioclase is extremely high and is always greater than that of alkali feldspar. The texture of the volcanic rocks is almost intersertal and (or) intergranular, and rarely sub-ophitic. Small amounts of interstitial glass always occur. Therefore these volcanic rocks were probably derived mostly from flows of acidic to intermediate composition, and partly from hypabyssal rocks. No clasts of plutonic rocks were observed in the conglomerate bed.

Plagioclase occurs both as phenocrysts and as a groundmass phase. Phenocryst plagioclase, nearly euhedral and up to $3 \mathrm{~mm}$, sometimes shows pronounced 
compositional zoning: a broad, highly calcic core surrounded by narrow, intensely zoned rims. Groundmass plagioclase occurs as small laths. Compositions of plagioclases are shown in Figure 1.

Plagioclase phenocrysts of andesitic and dacitic cobbles are very calcium-rich, sometimes reaching about $\mathrm{An}_{80}$ in the grain core, whereas the plagioclase of moreacidic rocks is less calcic. The $\mathrm{K}_{2} \mathrm{O}$ content of plagioclase increases as $\mathrm{Na}_{2} \mathrm{O}$ content increases, and the $\mathrm{K}_{2} \mathrm{O}$ content of phenocryst plagioclase is very low. Some plagioclase phenocrysts extremely rich in $\mathrm{CaO}$ have small glass inclusions, now altered to brown clay minerals. This type of plagioclase phenocryst is genetically significant and is sometimes observed in basaltic rocks. Judging from the very high calcium content of the broad core and the resorbed phenocrysts, this type of plagioclase is possibly a xenocryst derived from moremafic magma.
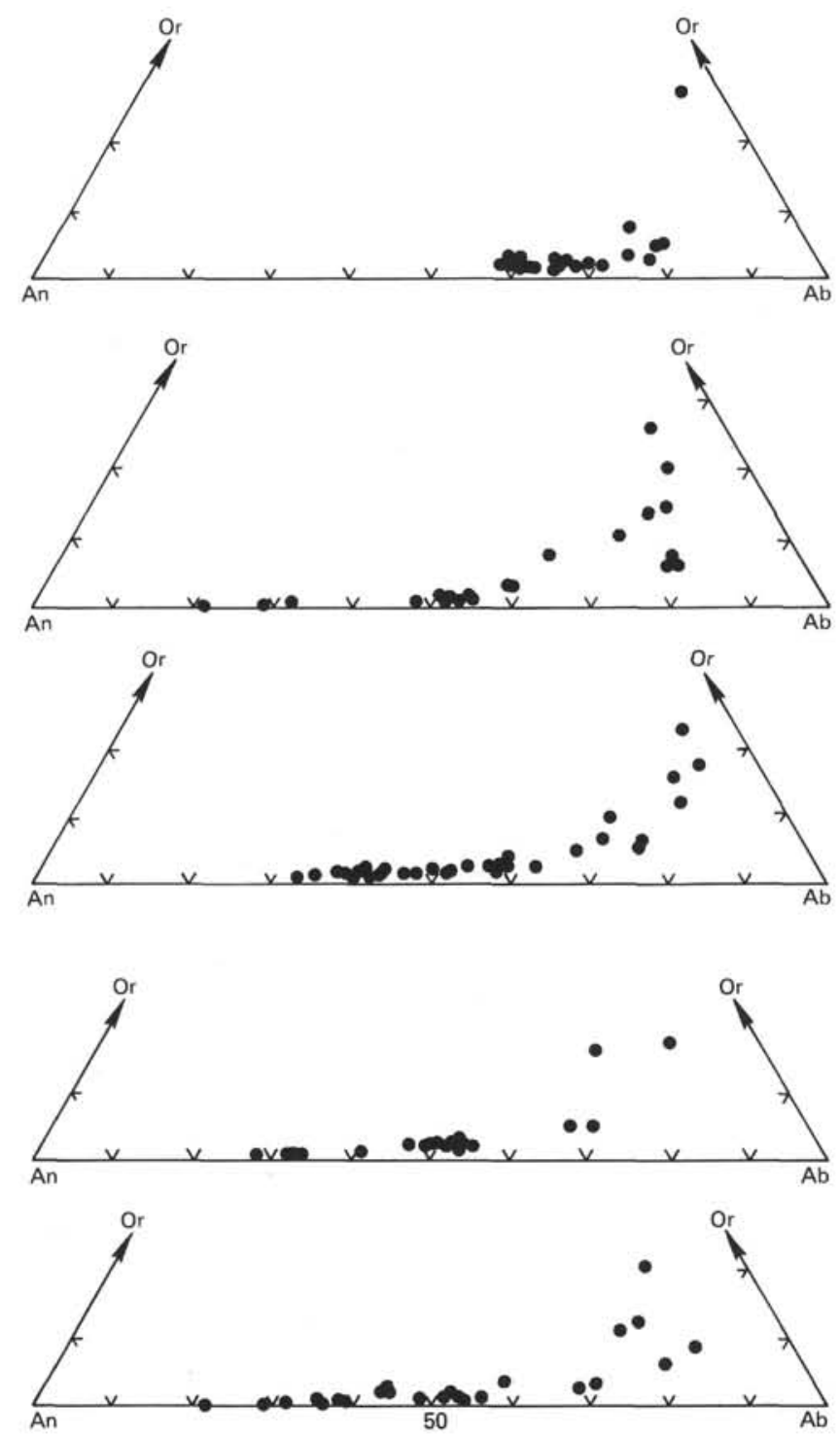

Figure 1. Or-Ab-An plot of plagioclases of the conglomerate bed.
Hornblende occurs as a phenocryst in andesite and dacite, but is absent in rhyolite. Figure 2 is photomicrograph of a typical hornblende dacite. Hornblende phenocrysts always change to aggregates of clay minerals at their peripheries. It is clear from Figure 2 that hornblende crystals are partly replaced along their rims, while the core of the crystals remains unaltered. These cores show pale-brownish-green, weak pleochroism. In some rocks only hornblende pseudomorphs are observed.

Chemical compositions of unaltered hornblende are listed in Table 1 . The $\mathrm{MgO}$ and $\mathrm{Al}_{2} \mathrm{O}_{3}$ contents of phenocryst plagioclase are higher than those of typical granitic rocks of the Kitakami Mountains, whereas $\mathrm{K}_{2} \mathrm{O}$, and total $\mathrm{Fe}$ contents are lower than those of granitic rocks (Kanisawa, 1972). In rims of hornblende the total $\mathrm{Fe}_{2} \mathrm{O}_{3}$ or $\mathrm{Fe}_{2} \mathrm{O}_{3} / \mathrm{MgO}$ ratio becomes higher than in the core.

Iron-oxide minerals are minor constituents and they are very fine grained; therefore the intensity of magnetization is very weak. The groundmass of these volcanic rocks has been altered to various degrees. Interstitial glass has mostly altered or devitrified to small

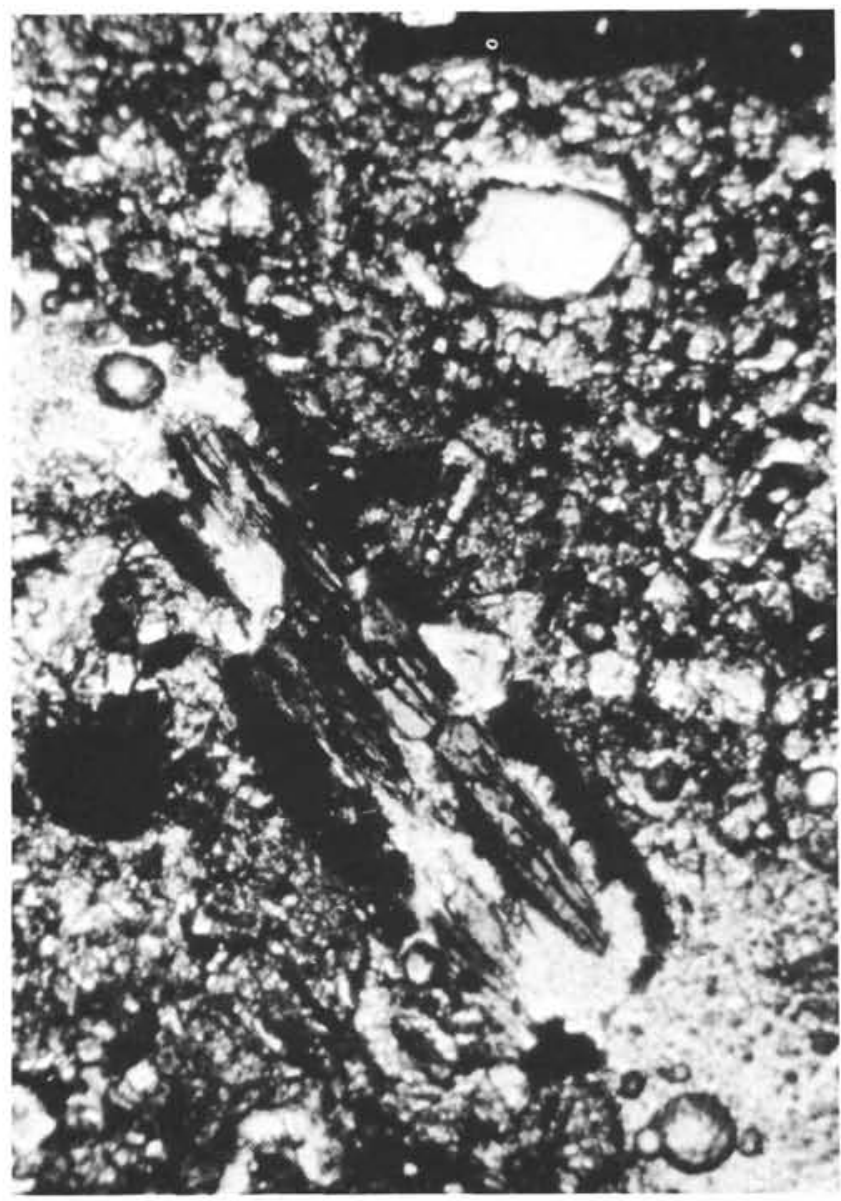

Figure 2. Photomicrograph of hornblende dacite. Hornblende phenocryst is partly replaced by small aggregates of clay minerals. 
TABLE 1

Chemical Compositions of Hornblende Phenocrysts ${ }^{a}$

\begin{tabular}{lrrrrrrrrrr}
\hline \multicolumn{3}{c}{$34-2,120-122 \mathrm{~cm}$} \\
\hline $\mathrm{SiO}_{2}$ & 46.15 & 45.06 & 46.06 & 45.53 & 46.97 & 44.47 & 46.43 & 44.00 & 42.23 & 42.32 \\
$\mathrm{TiO}_{2}$ & 1.47 & 1.68 & 1.47 & 1.36 & 1.43 & 1.63 & 1.08 & 1.55 & 1.32 & 1.58 \\
$\mathrm{Al}_{2} \mathrm{O}_{3}$ & 8.18 & 8.21 & 11.31 & 8.40 & 8.72 & 10.05 & 10.18 & 9.91 & 9.88 & 10.10 \\
$\mathrm{FeO}^{*}$ & 7.62 & 9.24 & 7.62 & 9.16 & 10.05 & 10.15 & 7.83 & 10.33 & 8.13 & 7.43 \\
$\mathrm{MnO}$ & 0.11 & 0.14 & 0.07 & 0.14 & 0.18 & 0.18 & 0.04 & 0.11 & 0.16 & 0.07 \\
$\mathrm{MgO}$ & 16.97 & 17.02 & 15.56 & 16.96 & 16.40 & 16.11 & 17.08 & 15.72 & 14.83 & 15.35 \\
$\mathrm{CaO}$ & 11.17 & 10.69 & 11.24 & 11.47 & 10.91 & 11.06 & 10.58 & 10.28 & 9.71 & 10.48 \\
$\mathrm{Na}_{2} \mathrm{O}$ & 2.81 & 3.03 & 2.45 & 2.74 & 2.94 & 2.90 & 2.74 & 3.38 & 3.13 & 2.95 \\
$\mathrm{~K}_{2} \mathrm{O}$ & 0.18 & 0.15 & 0.16 & 0.16 & 0.14 & 0.15 & 0.06 & 0.04 & 0.12 & 0.14 \\
\hline
\end{tabular}

*Total iron as $\mathrm{FeO}$.

aEPMA analyses.

aggregates of brown clay minerals. In some rocks, spherulitic chlorite and chalcedony are observed.

\section{CHEMICAL COMPOSITION OF THE VOLCANIC ROCKS}

\section{General Statement and Method of Analysis}

In order to classify the volcanic rocks of the conglomerate bed and determine their rock series, conventional XRF analyses were carried out for $\mathrm{SiO}_{2}, \mathrm{TiO}_{2}$, $\mathrm{Al}_{2} \mathrm{O}_{3}$, total iron as $\mathrm{Fe}_{2} \mathrm{O}_{3}, \mathrm{MnO}, \mathrm{MgO}, \mathrm{CaO}, \mathrm{Na}_{2} \mathrm{O}$, $\mathrm{K}_{2} \mathrm{O}$ and $\mathrm{P}_{2} \mathrm{O}_{5}$. The analytical method is as follows: First, the volcanic rocks are crushed with a ball mill, using a tungsten carbide cylinder for about 10 minutes, and then 1.000-gram powders are measured precisely; lithium borate powders of five times this weight are added as a flux. These powders are then fused in a furnace in a Pt95-Au5 crucible or dish at a temperature of about $1100^{\circ} \mathrm{C}$ for several tens of minutes. When all the crystals melt, the crucible is taken off the furnace. In this way, glassy pellets are prepared. Weight per cents of major elements are then measured by XRF calibration curves for all the elements, based on glass pellets of known chemical composition. The standards JB-1 and JG-1 are also used when unknown glass is measured. The precise method and experimental conditions were reported by Ohmori (1976), Ohmori and Ohmori (1976), Goto (1976), and Sugisaki et al. (1977).

Twenty-five volcanic rocks and three samples of matrix sediment were analyzed and are listed in Table 2. The $\mathrm{SiO}_{2}$ content of these volcanic rocks ranges from 60.23 to 73.90 weight per cent in water-free samples, corresponding to that of andesite to rhyolite. The most frequent rock type is dacite. All the samples show very high $\mathrm{Al}_{2} \mathrm{O}_{3}$ content, which reflects the large amount of modal plagioclase. The chemical composition of the matrix sediment is similar to that of the volcanic rocks, except that $\mathrm{CaO}$ content is low compared with that of the volcanic rocks. The low $\mathrm{CaO}$ content of the matrix sediments reflects the lower amount of plagioclase. Because the conglomerate clasts and matrix sediment are similar it is likely that the provenance of this conglomerate bed is not far from this site.

\section{$\mathrm{SiO}_{2}-\left(\mathrm{Na}_{2} \mathrm{O}+\mathrm{K}_{2} \mathrm{O}\right)$ Relation}

Classification of volcanic rocks according to their chemical compositions is very important, and many authors have proposed various diagrams and methods. In order to divide the volcanic rocks into alkalic rock series and non-alkalic rock series, the $\mathrm{SiO}_{2}-\left(\mathrm{Na}_{2} \mathrm{O}+\right.$ $\mathrm{K}_{2} \mathrm{O}$ ) diagram of Kuno $(1960,1966,1968)$ is very useful. Kuno (1966) has classified many volcanic rocks of the circum-Pacific region by using this diagram.

Macdonald and Katsura (1964) proposed a similar diagram for the Hawaiian basaltic rocks, but in the present case it seems to be better to use Kuno's diagram because the volcanic rocks have intermediate to acidic compositions. Figure 3 shows the $\mathrm{SiO}_{2}-\left(\mathrm{Na}_{2} \mathrm{O}+\mathrm{K}_{2} \mathrm{O}\right)$ relation of the volcanic rocks of the conglomerate bed. In this diagram, the areas $\mathrm{A}, \mathrm{B}$, and $\mathrm{C}$ represent alkali basalt, high-alumina basalt, and tholeiite respectively. All the volcanic rocks of the conglomerate bed fall in fields $B$ and $C$, suggesting that all the volcanic rocks belong to non-alkalic rock series. These volcanic rocks have suffered alteration to various degrees, and it is possible that $\mathrm{SiO}_{2}$ and alkalis have been removed during the alteration process. This problem seems to be significant and difficult to solve for the older volcanic rocks. The mobility of $\mathrm{SiO}_{2}$, alkalis, and other elements has been dealt with by many petrologists and geochemists (e.g., Hart, 1973), but this problem has not yet been clearly solved. Alteration products of these volcanic rocks do not exceed 15 volume per cent. Petrographic observations suggest that the most abundant alteration products are the small aggregates of clay minerals. In the case of volcanic rocks, as alteration proceeds there is a possibility that the amount of alkalis, especially $\mathrm{K}_{2} \mathrm{O}$, increases (Hart, 1973; Melson and Thompson, 1973).

In the $\mathrm{SiO}_{2}-\left(\mathrm{Na}_{2} \mathrm{O}+\mathrm{K}_{2} \mathrm{O}\right)$ diagram, a critical factor used to separate alkalic from non-alkalic rocks is the total alkali content.

\section{( $\left.\mathrm{FeO}^{*} / \mathrm{MgO}\right)-\mathrm{SiO}_{2}$ Relation}

Recently, Miyashiro $(1974,1975)$ tried to classify volcanic rocks of the non-alkalic series into two groups, calc-alkalic and tholeiitic, by compiling analyses of 
TABLE 2

XRF Bulk Analyses of Volcanic-Rock Clasts and Matrix of Conglomerate (wt. \%)

\begin{tabular}{|c|c|c|c|c|c|c|c|c|c|c|c|c|c|}
\hline \multirow[b]{2}{*}{ Component } & \multicolumn{13}{|c|}{ Sample Number and Interval (in $\mathrm{cm}$ ) } \\
\hline & $\begin{array}{c}1 \\
32-2 \\
61-62\end{array}$ & $\begin{array}{c}2 \\
33-1 \\
18-19\end{array}$ & $\begin{array}{c}3 \\
33-1, \\
94-95\end{array}$ & $\begin{array}{c}4 \\
33-1 \\
122-124 \text { (a) }\end{array}$ & $\begin{array}{c}5 \\
33-1 \\
122-124 \text { (b) }\end{array}$ & $\begin{array}{c}6 \\
33-1 \\
137-139\end{array}$ & $\begin{array}{c}7 \\
34-1 \\
34-35\end{array}$ & $\begin{array}{c}8 \\
34-1 \\
51-52\end{array}$ & $\begin{array}{c}9 \\
34-1 \\
140-143\end{array}$ & $\begin{array}{c}10 \\
34-2 \\
0-4\end{array}$ & $\begin{array}{c}11 \\
34-2 \\
30-32\end{array}$ & $\begin{array}{c}12 \\
34-2 \\
96-98\end{array}$ & $\begin{array}{c}13 \\
34-2 \\
99-101\end{array}$ \\
\hline $\mathrm{SiO}_{2}$ & 62.29 & 73.90 & 60.23 & 62.66 & 62.90 & 64.00 & 72.51 & 69.35 & 62.38 & 60.68 & 61.61 & 71.12 & 65.63 \\
\hline $\mathrm{TiO}_{2}$ & 0.43 & 0.18 & 0.43 & 0.40 & 0.40 & 0.42 & 0.72 & 0.77 & 0.43 & 0.41 & 0.43 & 0.54 & 0.37 \\
\hline $\mathrm{Al}_{2} \mathrm{O}_{3}$ & 24.34 & 16.67 & 24.92 & 23.91 & 23.68 & 24.84 & 18.23 & 20.09 & 24.45 & 24.98 & 25.63 & 15.97 & 23.47 \\
\hline $\mathrm{Fe}_{2} \mathrm{O}_{3} *$ & 1.79 & 1.57 & 3.13 & 3.22 & 3.16 & 2.22 & 3.45 & 3.69 & 2.05 & 1.82 & 1.43 & 3.52 & 1.63 \\
\hline $\mathrm{MnO}$ & 0.00 & 0.04 & 0.00 & 0.00 & 0.00 & 0.00 & 0.00 & 0.03 & 0.00 & 0.00 & 0.00 & 0.05 & 0.03 \\
\hline $\mathrm{MgO}$ & 0.49 & 0.19 & 0.94 & 0.91 & 0.92 & 0.79 & 0.86 & 1.07 & 0.25 & 0.24 & 0.21 & 1.48 & 0.44 \\
\hline $\mathrm{CaO}$ & 4.71 & 1.81 & 5.19 & 4.40 & 4.39 & 3.63 & 0.25 & 0.48 & 4.77 & 5.57 & 4.58 & 1.80 & 3.62 \\
\hline $\mathrm{Na}_{2} \mathrm{O}$ & 4.25 & 4.10 & 3.70 & 3.30 & 3.35 & 2.92 & 1.65 & 1.65 & 4.40 & 4.95 & 4.74 & 2.97 & 3.69 \\
\hline $\mathrm{K}_{2} \mathrm{O}$ & 1.60 & 1.44 & 1.44 & 1.17 & 1.18 & 1.17 & 2.30 & 2.85 & 1.09 & 1.11 & 1.05 & 2.47 & 1.04 \\
\hline $\mathrm{P}_{2} \mathrm{O}_{5}$ & 0.11 & 0.09 & 0.03 & 0.03 & 0.02 & 0.02 & 0.03 & 0.01 & 0.19 & 0.24 & 0.31 & 0.07 & 0.09 \\
\hline Total Alkali & 5.85 & 5.54 & 5.14 & 4.47 & 4.53 & 4.09 & 3.95 & 4.50 & 5.49 & 6.06 & 5.79 & 5.44 & 4.73 \\
\hline $\mathrm{FeO}$ & 1.61 & 1.41 & 2.82 & 2.90 & 2.84 & 2.00 & 3.11 & 3.32 & 1.85 & 1.64 & 1.29 & 3.17 & 1.47 \\
\hline $\mathrm{MgO} / \mathrm{FeO}^{*}$ & 3.29 & 7.42 & 3.00 & 3.19 & 3.09 & 2.53 & 3.62 & 3.10 & 7.40 & 6.83 & 6.14 & 2.14 & 3.34 \\
\hline
\end{tabular}

*Total iron as $\mathrm{Fe}_{2} \mathrm{O}_{3}$ or $\mathrm{FeO}$.

many volcanic rocks from various tectonic settings. $\mathrm{He}$ proposed an $(\mathrm{FeO} * / \mathrm{MgO})-\mathrm{SiO}_{2}$ diagram as a critical indicator. ( $\mathrm{FeO}^{*}$ is total iron as $\mathrm{FeO}$.)

His method is thought to be most useful for the intermediate to basic rocks with $\mathrm{FeO}^{*} / \mathrm{MgO}$ ratios of 2 to 5. However, we have no critical factor to distinguish between calc-alkalic rocks and tholeiitic rocks with more acidic chemical composition. Therefore, in order to classify the volcanic rocks in the present study, the ( $\mathrm{FeO} * / \mathrm{MgO})-\mathrm{SiO}_{2}$ diagram proposed by Miyashiro was used. These data are plotted in Figure 4. The equation separating the calc-alkalic and tholeiitic fields was obtained by Miyashiro (1974) using the relation $\mathrm{SiO}_{2}=$ $[6.4 \times(\mathrm{FeO} * / \mathrm{MgO})]+42.8$.

In Figure 4, the data are somewhat scattered, but there is a concentration in a narrow region. The analyzed matrix sediments fall within the calc-alkalic area. $\mathrm{FeO}^{*}$ and $\mathrm{MgO}$ and the $\mathrm{FeO} * / \mathrm{MgO}$ ratio may not be as changeable during the alteration process compared with other components, and the matrix sediments may be derived from calc-alkalic source rocks. The ratio of the calc-alkalic to the tholeiitic points is high, showing that the dominant rock series forming the volcanic rocks of the conglomerate bed is the calc-alkalic one.

\section{Variation Diagram}

Figure 5 is an oxide variation diagram. The horizontal axis is $\mathrm{SiO}_{2}$, because the $\mathrm{Fe}_{2} \mathrm{O}_{3} / \mathrm{FeO}$ ratio of the volcanic rocks is unknown, and normative minerals therefore could not be calculated. In the calc-alkalic rocks, $\mathrm{SiO}_{2}$ content is a good indicator of the degree of differentiation. In this figure, $\mathrm{Al}_{2} \mathrm{O}_{3}$ and $\mathrm{CaO}$ decrease as $\mathrm{SiO}_{2}$ increases, suggesting that differentiation may have been controlled by fractional crystallization of plagioclase. However, $\mathrm{Na}_{2} \mathrm{O}$ and $\mathrm{K}_{2} \mathrm{O}$ do not show a distinct relation to $\mathrm{SiO}_{2}$. $\mathrm{FeO}^{*}$ and $\mathrm{MgO}$ do not change much as $\mathrm{SiO}_{2}$ increases. The $\mathrm{FeO} * / \mathrm{MgO}$ ratio changes significantly in the $(\mathrm{FeO} * / \mathrm{MgO})-\mathrm{SiO}_{2}$ diagram (Figure 4). This suggests that differentiation of these volcanic rocks was controlled not only by fractional crystallization of plagioclase, but also by that of hornblende and K-feld- spar, and that the $\mathrm{FeO}^{*} / \mathrm{MgO}$ ratio depends on the local amount of mafic minerals.

\section{$\mathrm{FeO}^{*}-\left(\mathrm{Na}_{2} \mathrm{O}+\mathrm{K}_{2} \mathrm{O}\right)-\mathrm{MgO}$ (AFM) Diagram}

In AFM diagrams, differentiation trends of the calcalkalic rock series and the tholeiitic series are different. The plots for acidic volcanic rocks of this study are shown in Figure 6. The data plot near the total-alkali corner, indicating highly differentiated rocks. A good linear relation is exhibited in this diagram, suggesting that all of the analyzed volcanic rocks, although they occur as clasts in a conglomerate, have a close genetic relationship with one another and that differentiation was controlled by fractional crystallization of plagioclase. The trend shown by these volcanic rocks is similar to that of typical calc-alkalic rocks.

\section{TECTONIC SETTING OF THE VOLCANIC ROCKS}

Miyashiro $(1974,1975)$ compiled analyses of non-alkalic rocks and proposed a method of classification of the calc-alkalic and tholeiitic series. He also discussed the relationship between volcanic rock series and tectonics.

The acidic volcanic rocks of the Site 439 conglomerate belong to both the calc-alkalic and tholeitic series. In modern island arcs along active continental margins, assemblages of tholeiitic and calc-alkalic volcanic rocks are always observed. In highly matured island arcs, and assemblage of tholeiitic, calc-alkalic, and small amounts of alkalic volcanic rocks is frequently observed.

Judging from the assemblage of rock series and the frequency of calc-alkalic and tholeiitic rock series of the volcanic rocks of the conglomerate bed in Lithologic Unit 6 of Site 439, the source region of the conglomerates is thought to be an island arc (Oyashio ancient landmass; Site 438-439 Report, this volume).

\section{MAGNETIC PROPERTIES OF THE VOLCANIC ROCKS}

In order to determine whether these volcanic rocks have suffered extensively from low-temperature oxida- 
TABLE 2 - Continued

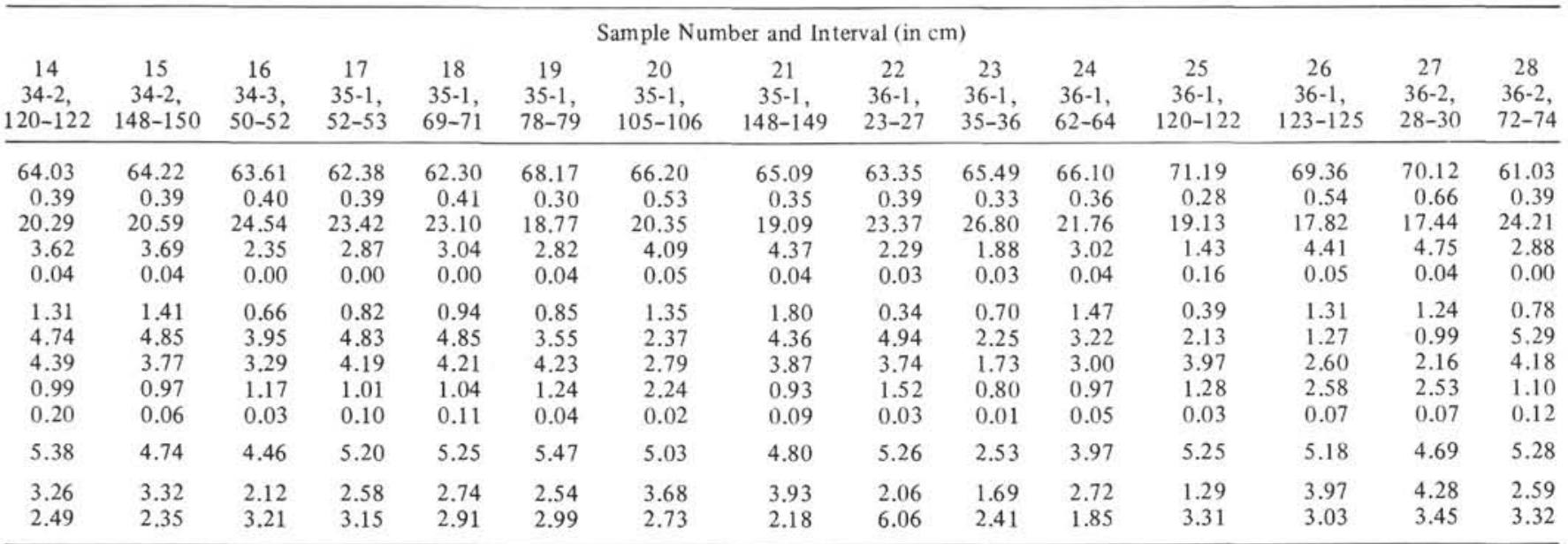

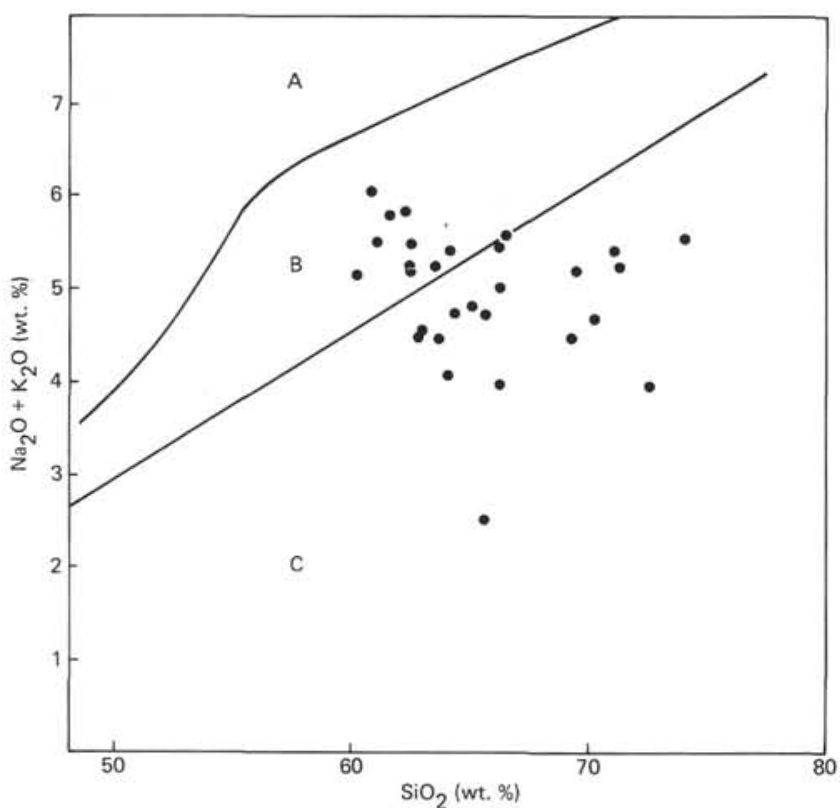

Figure 3. $\mathrm{SiO}_{2}-\left(\mathrm{Na}_{2} \mathrm{O}+\mathrm{K}_{2} \mathrm{O}\right)$ diagram.

tion a study of their magnetism was carried out. From the results, the environment in which the volcanic rocks were erupted can be estimated.

The total magnetic intensity of a whole-rock sample was measured with a spinner magnetometer. The intensity is $6.58 \times 10^{-6} \mathrm{emu} / \mathrm{g}$. This value is slightly lower than that of other acidic volcanic rocks. As these volcanic rocks have very small modal amounts of ironoxide minerals, this low value seems reasonable. A thermomagnetic measurement was also carried out with a magnetic balance in order to estimate the Curie temperature and to draw a thermomagnetic curve of the volcanic rock (Figure 7). The Curie point of this rock is $545^{\circ} \mathrm{C}$, and this temperature suggests that the magnetic minerals of the volcanic rock are nearly stoichiometric magnetite, deviating slightly from the stoichiometric magnetite-titanomagnetite line. The thermomagnetic curve resembles a reversible type, but suggests that this

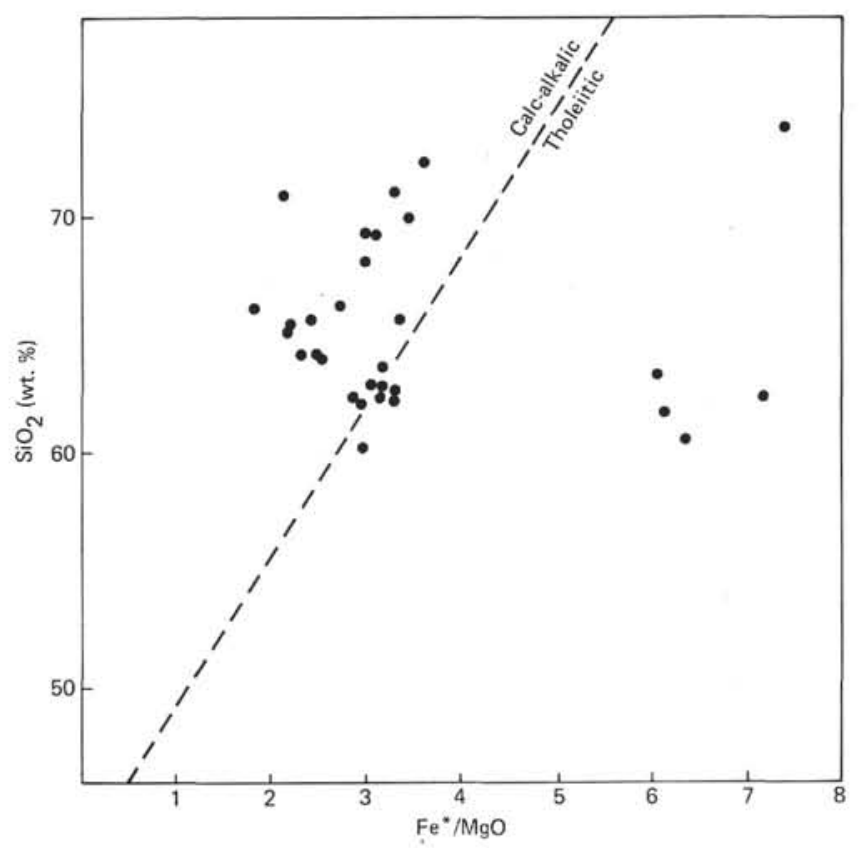

Figure 4. $(\mathrm{FeO} * / \mathrm{MgO})-\mathrm{SiO}_{2}$ diagram. $\mathrm{FeO} *$ represents total iron as $\mathrm{FeO}$.

rock suffered neither from low- nor high-temperature oxidation. Nevertheless, there is some possibility that this rock was erupted subaerially. Further investigation of the magnetism of these volcanic rocks is necessary.

\section{AGE OF THE VOLCANIC ROCKS}

${ }^{40} \mathrm{Ar} /{ }^{39} \mathrm{Ar}$ dating of these volcanic rocks was carried out by Yanagisawa et al. (this volume). According to them, the absolute isochron age ranges from 21.2 to $22.8 \mathrm{~m} . \mathrm{y}$. and averages $21.4 \pm 1.0 \mathrm{~m} . \mathrm{y}$. (that is, uppermost Oligocene to lowermost Miocene, corresponding to magnetic anomaly $6 \mathrm{~B}$ ).

Volcanism of the same age is recorded on the Oga Peninsula (Konda, 1974; Nishimura and Ishida, 1972), in the western part of the Tohoku arc, and in the eastern part of the Tohoku arc of Honshu (Takadate andesite). 

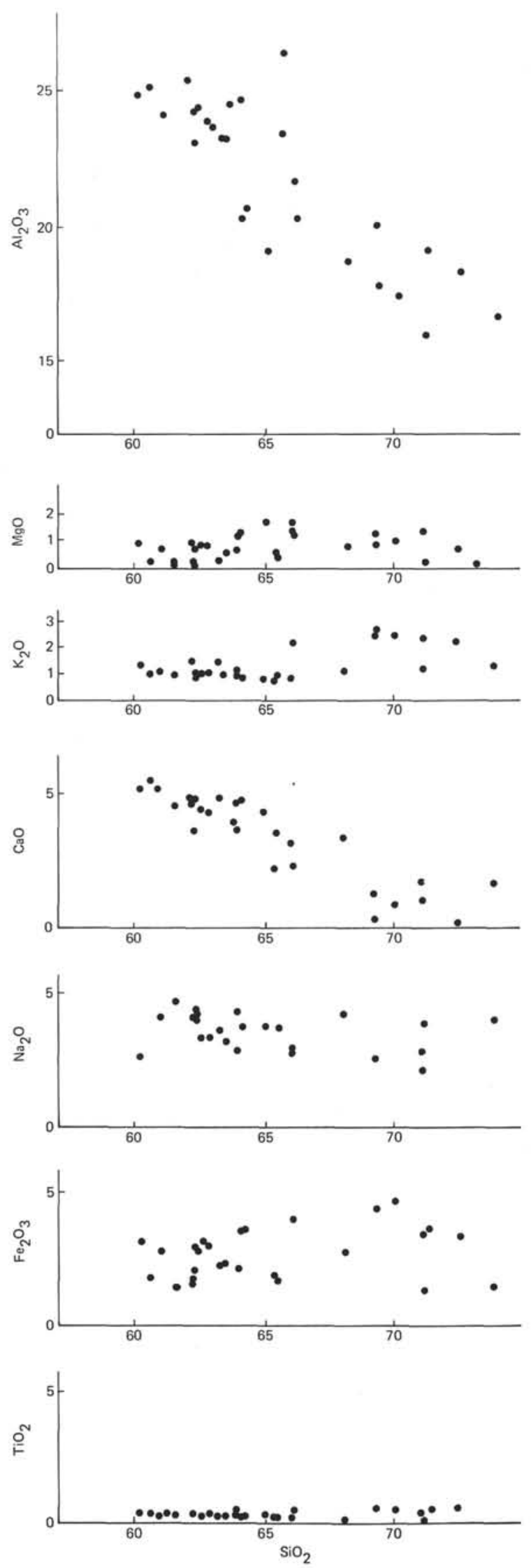

Figure 5. Oxide variation diagram. All values in weight per cent.

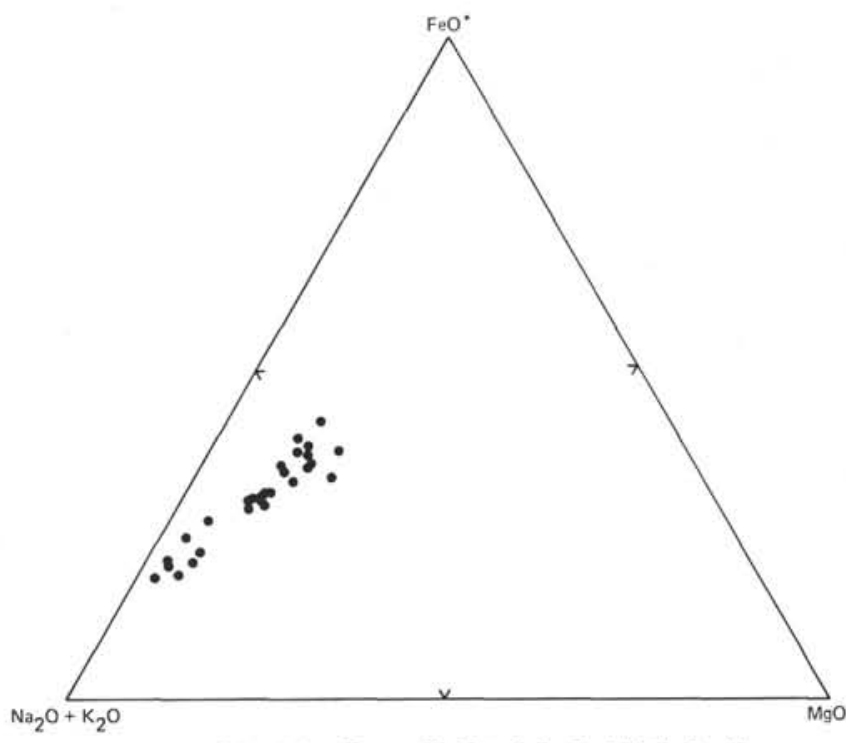

Figure 6. $\mathrm{FeO}^{*}-\left(\mathrm{Na}_{2} \mathrm{O}+\mathrm{K}_{2} \mathrm{O}\right)-\mathrm{MgO}$ (AFM) diagram. $\mathrm{FeO} *$ represents total iron as $\mathrm{FeO}$.

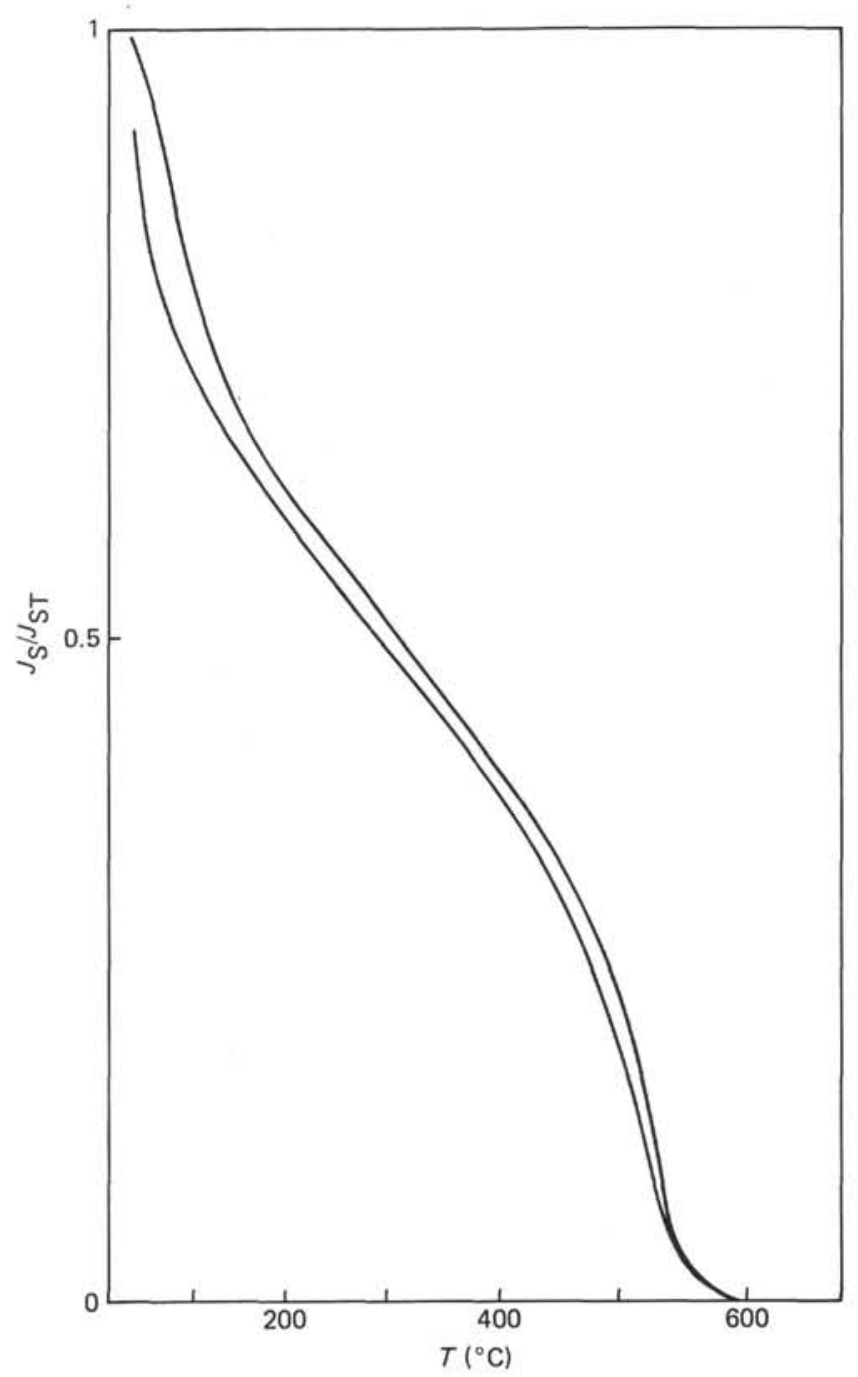

Figure 7. Thermomagnetic curve of volcanic rock from $439-33-1,122-124 \mathrm{~cm}$. 


\section{DISCUSSION}

Major-element chemical analyses of the acidic volcanic rocks of the conglomerate bed show that all the volcanic rocks belong to the non-alkalic rock series, according to Kuno's silica-alkali diagram. The volcanic rocks plot in both the calc-alkalic and the tholeiitic fields of the $(\mathrm{FeO} * / \mathrm{MgO})-\mathrm{SiO}_{2}$ diagram of Miyashiro. The volcanic rocks have a genetic similarity to one another in various diagrams, and therefore the tectonic setting of these volcanic rocks is inferred to have been an island arc.

The $\mathrm{K}_{2} \mathrm{O}$ content of volcanic rocks is a useful indicator of the depth of the Benioff zone and distance from the trench axis (Dickinson, 1968; Dickinson and Hatherton, 1967; Nielson and Stoiber, 1973). Recently, Miyashiro showed variation between $\mathrm{K}_{2} \mathrm{O}$ and $\mathrm{SiO}_{2}$ of volcanic rocks of various island arcs and active continental margins with advancing development of continental-type crust (that is, with the degree of maturity of the arcs and continental margins). He compared many volcanic rocks from various island arcs, plotting them on the $\mathrm{K}_{2} \mathrm{O}-\mathrm{SiO}_{2}$ diagram.

In the $\mathrm{K}_{2} \mathrm{O}-\mathrm{SiO}_{2}$ diagram, the volcanic rocks from immature island arcs plot around the low- $\mathrm{K}_{2} \mathrm{O}$ regions, whereas those from highly mature island arcs plot in the high $-\mathrm{K}_{2} \mathrm{O}$ areas. To estimate the maturity of the Oyashio ancient landmass, which presumably supplied conglomerates and clastics to Site 439 , the data are plotted on this diagram (Figure 8A), with Miyashiro's figure for comparison (Figure 8B). In this figure, the data for the present study plot in a narrow low $-\mathrm{K}_{2} \mathrm{O}$ area. This relation is very similar to that for volcanic rocks obtained between the northeast Japan outer arc and inner arc of Miyashiro's figure. This suggests that in size and maturity the Oyashio ancient landmass was the same as the above-mentioned arcs.

\section{ACKNOWLEDGMENTS}

The author sincerely thanks Drs. N. Nasu, K. Kobayashi, and T. Ishii, Ocean Research Institute, University of Tokyo, who read this manuscript critically and gave fruitful discussions in the course of preparing this paper. The author also expresses his thanks to Drs. R. von Huene and M. Arthur and all the shipboard scientists for their continuous encouragement.

\section{REFERENCES}

Dickinson, W. R., 1968. Circum-Pacific andesite types. J. Geophys. Res., 73, 2261-2269.

Dickinson, W. R., and Hatherton, T., 1967. Andesitic volcanism and seismicity around the Pacific. Science, 157, 801-803

Goto, H., 1976. Automatic analysis of major elements in silicate rocks by X-ray fluorescence spectrometry. Bull. Geol. Surv. Jap., 27, 595-611. [In Japanese with English abstract]

Kanisawa, S., 1972. Coexisting biotites and hornblendes from some granitic rocks in southern Kitakami Mountains, Japan. J. Jap. Assoc. Mineral. Petrol. Econ. Geol., 67, 332344.

Konda, T., 1974. Bimodal volcanism in the Northeast Japan arc. J. Geol. Soc. Jap., 80, 81-89.
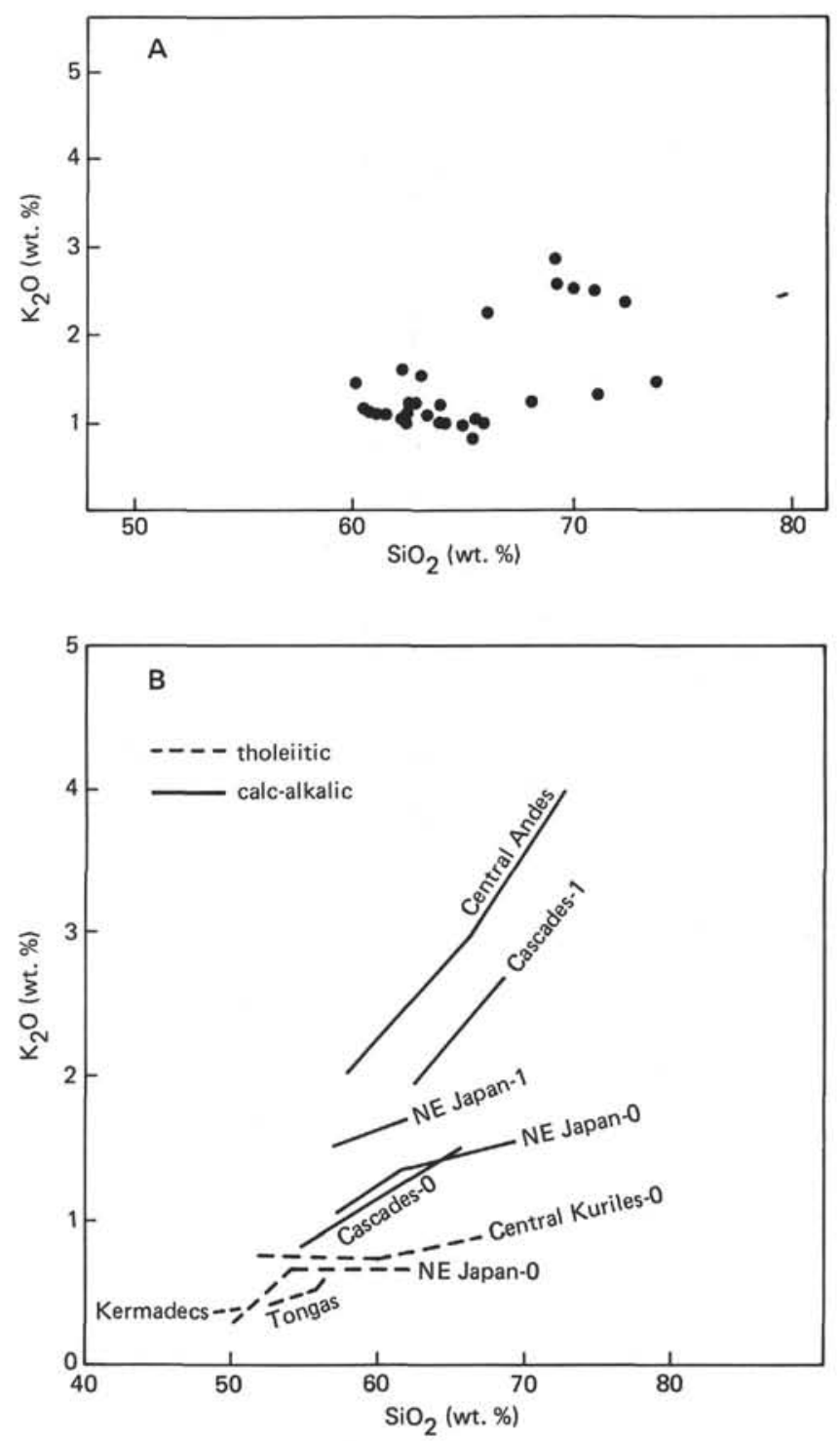

Figure 8. A. $\mathrm{K}_{2} \mathrm{O}-\mathrm{SiO}_{2}$ plot of the volcanic rocks. B. Same diagram compiled by Miyashiro (1974).

Kuno, H., 1960. High-alumina basalt. J. Petrol., 1, 121-145. 1966. Lateral variation of basalt magma type across continental margins and island arcs. Bull. Volcanol., 29, 195-222.

, 1968. Origin of andesite and its bearing on the island arc structure. Bull. Volcanol., 32, 141-176.

Hart, R., 1973. A model for chemical exchange in basalt-seawater system of Oceanic Layer II. Can. J. Earth Sci., 10, 799-816.

Macdonald, G. A., and Katsura, T., 1964. Chemical composition of Hawaiian lavas. J. Petrol., 5, 82-133.

Melson, W. G., and Thompson, G., 1973. Glassy abyssal basalts, Atlantic sea floor near St. Paul's rocks: petrography and composition of secondary clay minerals. Geol. Soc. Am. Bull., 84, 703-716.

Miyashiro, A., 1974. Volcanic rock series in island arcs and active continental margins. Am. J. Sci., 274, 321-355.

1975. Volcanic rock series and tectonic setting. Earth Planet. Sci. Lett. Ann. Rev., 16, 251-269. 


\section{K. FUJIOKA}

Nielson, D. R., and Stoiber, R. E., 1973. Relationship of potassium content in andesite lavas and depth of the seismic zone. J. Geophys. Res., 78, 6887-6892.

Nishimura, S., and Ishida, S., 1972. Fission-track ages of tuffs of the Neogene-Tertiary in Oga Peninsula, Akita Prefecture Japan. J. Jap. Assoc. Mineral. Petrol. Econ. Geol., 67, 166168. [In Japanese with English abstract]
Ohmori, T., and Ohmori, E., 1976. X-ray fluorescence analysis of major elements in rocks and minerals. Part 1. Bull. Geol. Surv. Jap., 27, 195-211.

Sugisaki, R., et al., 1977. An automatic X-ray fluorescence method for the analysis of silicate rocks. J. Geol. Soc. Jap., $83,725-733$.

von Huene, R., and Nasu, N., et al., 1978. Japan Trench transected. Geotimes, 23, 16-21. 